\title{
Paclobutrazol Distribution following Application to Two Media as Determined by Bioassay
}

\author{
Jeff B. Million, James E. Barrett, Terril A. Nell, and David G. Clark \\ Department of Environmental Horticulture, University of Florida, Gainesville, \\ FL 32611-0670
}

Additional index words. Brassica oleracea var. botrytis, broccoli, chrysanthemum, Dendranthema $\times$ grandiflora, drench, growth regulator, growth retardant, pine bark, subirrigation

\begin{abstract}
A broccoli (Brassica oleracea var. botrytis L.) seedling bioassay was used to measure paclobutrazol activity and distribution in two growing media following drench or subirrigation applications. The bioassay exhibited a saturation-type response curve for paclobutrazol concentrations up to $1000 \mu \mathrm{g} \cdot \mathrm{L}^{-1}$ in solution and $100 \mu \mathrm{g} \cdot \mathrm{L}^{-1}$ in the media. The concentration of paclobutrazol required to achieve one-half of the maximum observed bioassay activity was 3-fold as high in bark-based commercial potting medium as in a peatbased medium. Less than $2 \%$ of applied paclobutrazol leached out during the drench application despite the collection of up to $50 \mathrm{~mL}$ of leachate per $120 \mathrm{~mL}$ of the solution $(1000$ $\mu \mathrm{g} \cdot \mathrm{L}^{-1}$ ) that was applied per $15-\mathrm{cm}$ pot. Immediately following drench application, paclobutrazol concentrations in both media were highest in the uppermost $2.5 \mathrm{~cm}$ and decreased downward. By 3 weeks after treatment, drench-applied paclobutrazol had moved into lower depths. Distribution of paclobutrazol was limited to the bottom $2.5 \mathrm{~cm}$ of media when applied as a subirrigation soak. Chemical name used: $( \pm)-\left(\mathbf{R}^{*}, \mathbf{R}^{*}\right)-\beta-[(4-$ chlorophenyl)methyl]- $\alpha$-(1,1-dimethyl)-1H-1,2,4-triazole-1-ethanol (paclobutrazol).
\end{abstract}

Paclobutrazol is a growth retardant used in commercial floriculture to control plant size and quality. Although commonly applied as a foliar spray, it also can be applied as a medium drench. This increases its activity and results in fewer problems with excessive stunting or delayed flowering.

Factors affecting paclobutrazol activity and movement in soil and soilless media have received very little attention compared to the multitude of studies on its distribution in plants (Davis et al., 1988). This inattention may be attributed in part to the exacting laboratory procedures required for paclobutrazol measurement (Reed, 1988). The use of bioassays for quantifying the activity of growth retardants has proved useful in a limited number of studies. Hunter and Proctor (1990) described a grape (Vitis sp.) axillary shoot bioassay for paclobutrazol. They found specific leaf mass was log-linearly correlated with soil paclobutrazol concentration from 1 to $1000 \mu \mathrm{g} \cdot \mathrm{L}^{-1}$ of soil. McArthur and Eaton (1987) used a bioassay with rape (Brassica napus L.) and observed residual paclobutrazol activity in the soil 11 weeks after a foliar application to strawberry (Fragaria $\times$ ananassa Duchesne).

Received for publication 5 Feb. 1997. Accepted for publication 8 May 1998. Florida Agricultural Experiment Station Journal Series no. R-05636. We thank Carolyn Bartuska (Dept. of Environmental Horticulture) and Jay Harrison (Dept. of Statistics) for support of this project. The cost of publishing this paper was defrayed in part by the payment of page charges. Under postal regulations, this paper therefore must be hereby marked advertisement solely to indicate this fact.

HortSCIEnCE, Vol. 34(6), OCtOBER 1999

Tschabold et al. (1975) used foxtail mille [Setaria italica (L.) Beauv.] in leaching studies with ancymidol [ $\alpha$-cyclopropyl- $\alpha$-(4methoxyphenyl)-5-pyrimidinemethanol]; however, they provided no standard curve for response.

Composition of the growing media can affect the activity and distribution of plant growth regulators. Pine bark has been implicated in the reduced efficacy of ancymidol (Bonaminio and Larsen, 1978; Tschabold et al., 1975), as well as of paclobutrazol and flurprimidol $\{n-(1-$ methylethyl)-n-[4-(trifluourmethoxy)phenyl]5-pyrimidinemethanol\} (Barrett, 1982; Million et al., 1998). Reduced effectiveness of these growth retardants has generally been attributed to increased adsorption by the bark component. However, Bhat and Tayama (1990) concluded that the reduced effectiveness of ancymidol in bark-based media was due to increased leaching losses associated with the physical changes imparted by the bark.

We utilized a bioassay procedure for measuring paclobutrazol in growing media and leachates. The bioassay was used to determine the distribution of paclobutrazol a) when applied as a drench in two commercial growing media (Expt. 1) and b) when applied as a drench vs. a subsurface application (Expt. 2).

\section{Materials and Methods}

Bioassay procedure and standard curves. The two media tested were: a) Metro Mix 500 (MM500) (O.M. Scotts, Marysville, Ohio) composed (volume basis) of $20 \%$ sphagnum peat, $30 \%$ vermiculite, $40 \%$ composted pine bark, $10 \%$ processed pine bark ash, and b) Vergro Klay Mix A(VKMA) (Verlite, Tampa, Fla.) composed of $50 \%$ sphagnum peat, $20 \%$ vermiculite, $20 \%$ perlite, and $10 \%$ calcined clay. Broccoli was chosen as a bioassay crop because preliminary trials indicated that it was sensitive to the growth retardants in the range of concentrations typically found with media applications.

To establish a standard response curve 100-mL solutions of paclobutrazol $(0,10,25$, $50,75,100,250,500,750,1000$, and 2000 $\mu \mathrm{g} \cdot \mathrm{L}^{-1}$ ) were mixed with 1 -L batches of media premoistened with tap water. Each batch of medium was mixed uniformly by shaking and massaging in a polyethylene bag and was placed into twelve $4 \times 4 \mathrm{~cm}$ "cell-pack" cells each $5 \mathrm{~cm}$ deep. Six broccoli seeds were planted in each cell, and the cell-packs were placed in a greenhouse on capillary matting. Seedlings were thinned to two per cell $5 \mathrm{~d}$ after sowing. Average daily minimum and maximum temperatures were 19 and $30^{\circ} \mathrm{C}$, respectively. The cells were subirrigated continuously with fertilizer solution $(20 \mathrm{~N}-4.4 \mathrm{P}-16.6 \mathrm{~K}$ with micronutrients; O.M. Scotts Co., Marysville, Ohio), with $\mathrm{N}$ at $150 \mathrm{mg} \cdot \mathrm{L}^{-1}$.

A bioassay procedure for estimating paclobutrazol concentration in solutions was accomplished by pipetting $2 \mathrm{~mL}$ of standard solution into each of 12 vermiculite-filled cells. Nine standard concentrations ranging from 0 to $1000 \mu \mathrm{g} \cdot \mathrm{L}^{-1}$ were included to establish a standard response curve. Broccoli was planted in the cells and the test carried out as described above.
After $12 \mathrm{~d}$, seedlings from both bioassay procedures were cut at the medium surface and the hypocotyl length from the base to the cotyledonary node was measured to the nearest $\mathrm{mm}$. Bioassay activity was expressed as inhibition relative to the control:

$$
\mathrm{I}_{\mathrm{x}}=\left(\mathrm{H}_{0}-\mathrm{H}_{\mathrm{x}}\right) / \mathrm{H}_{0}
$$

where $I_{x}=$ inhibition at concentration $x, H_{x}=$ hypocotyl length at concentration $\mathrm{x}$, and $\mathrm{H}_{0}=$ mean hypocotyl length of the controls. A derivative-free (DUD) nonlinear regression procedure (PROC NLIN) (SAS Institute, 1987) was used to fit a Michaelis-Menten equation (Causton, 1983) to the standard curve data for each medium.

Media effects on drench distribution (Expt. 1). To determine the distribution of paclobutrazol following drench treatments, $15-\mathrm{cm}$ (1400-mL) pots were filled $11 \mathrm{~cm}$ deep with either VKMA or MM500. The filled pots were watered with tap water until the media were saturated. After settling, medium depth was $\approx 10 \mathrm{~cm}$. All pots were allowed to stand for 24 $\mathrm{h}$, at which time $120 \mathrm{~mL}$ of paclobutrazol at 0 or $1000 \mu \mathrm{g} \cdot \mathrm{L}^{-1}$ were applied to the surface of each pot $(0$ or $120 \mu \mathrm{g} / \mathrm{pot})$ (eight pots per treatment). Leachates from the drench application were collected from each pot and their volumes measured.

Paclobutrazol in the leachates was bioassayed immediately by pipetting $2 \mathrm{~mL}$ of leachate from each pot onto each of 12 vermiculite-filled cells. This procedure was carried out at the same time and in the same 
manner as described previously for the standards. Paclobutrazol activity in the leachate was expressed as inhibition using the hypocotyl length of the $0 \mu \mathrm{g} \cdot \mathrm{L}^{-1}$ treatment as $\mathrm{H}_{0}$. The Michaelis-Menten regression equation fitted to the standard curve data was subsequently used to estimate paclobutrazol concentration in the leachates.

Treated medium from each pot was divided into four depths: 0-2.5, 2.5-5, 5-7.5, and $7.5-10 \mathrm{~cm}$. For the bioassay, each sample was mixed and placed into six cells. This bioassay was conducted at the same time and under the same conditions as the standard curve series described previously. For each medium, inhibition was calculated separately for each sample depth using the control hypocotyl length of the $0 \mu \mathrm{g} \cdot \mathrm{L}^{-1}$ rate for a given sample depth as $\mathrm{H}_{0}$. Analysis of variance (ANOVA) was used to evaluate treatment effects on hypocotyl length.

A completely randomized design was used for analyzing leachate data, while a split-plot design was used to analyze media data. Drench concentration was the main plot factor and layer depth was the subplot factor. Because inhibition was calculated using the $0 \mu \mathrm{g} \cdot \mathrm{L}^{-1}$ treatment results, only media and sample depth were included as treatment effects in the ANOVA for this variable. Treatment means for inhibition were used to estimate paclobutrazol concentration according to bioassay standard curve regression equations.

Effect of application method on paclobutrazol distribution (Expt. 2). Three rooted cuttings of chrysanthemum [Dendranthema $\times$ grandiflora (Ramat.) cv. Nob Hill] were planted per $15-\mathrm{cm}(1400-\mathrm{mL})$ pot filled with VKMA. Plants were grown in a greenhouse with light levels between 800 and 1000 $\mu \mathrm{mol} \cdot \mathrm{m}^{-2} \cdot \mathrm{s}^{-1}$, and average minimum and maximum temperatures of $19^{\circ} \mathrm{C}$ and $28^{\circ} \mathrm{C}$, respectively. Plants were fertilized at every watering with a nutrient solution $(20 \mathrm{~N}-4.4 \mathrm{P}-16.6 \mathrm{~K}$ with minor elements; O.M. Scotts, Marysville, Ohio) containing $\mathrm{N}$ at $300 \mathrm{mg} \cdot \mathrm{L}^{-1}$. Paclobutrazol concentrations of 0 or $500 \mu \mathrm{g} \cdot \mathrm{L}^{-1}$ were applied as either a drench or through a subirrigation soak in a randomized block design with four blocks and four pots per block. All pots were treated $10 \mathrm{~d}$ after transplanting when roots had reached the edges of the pot. Subirrigation treatments were accomplished by placing preweighed pots in trays maintained $2-\mathrm{cm}$ deep with either 0 or $500 \mu \mathrm{g} \cdot \mathrm{L}^{-1}$ of paclobutrazol solution. After $20 \mathrm{~min}$, pots were removed and weighed to determine the volume of solution applied by subirrigation. Equivalent volumes were then applied to the surface for drench treatments. Two pots per block were sampled immediately after treatment and the distribution of paclobutrazol among the four sample depths was determined by the bioassay procedure (Expt. 1).

For the drench treatments only, the remaining two pots per block were sampled three weeks after treatment and the paclobutrazol bioassay was repeated. Separate standard curves were included for both sampling dates. We excluded the subirrigation treatments for the 3-week sampling because the use of over-

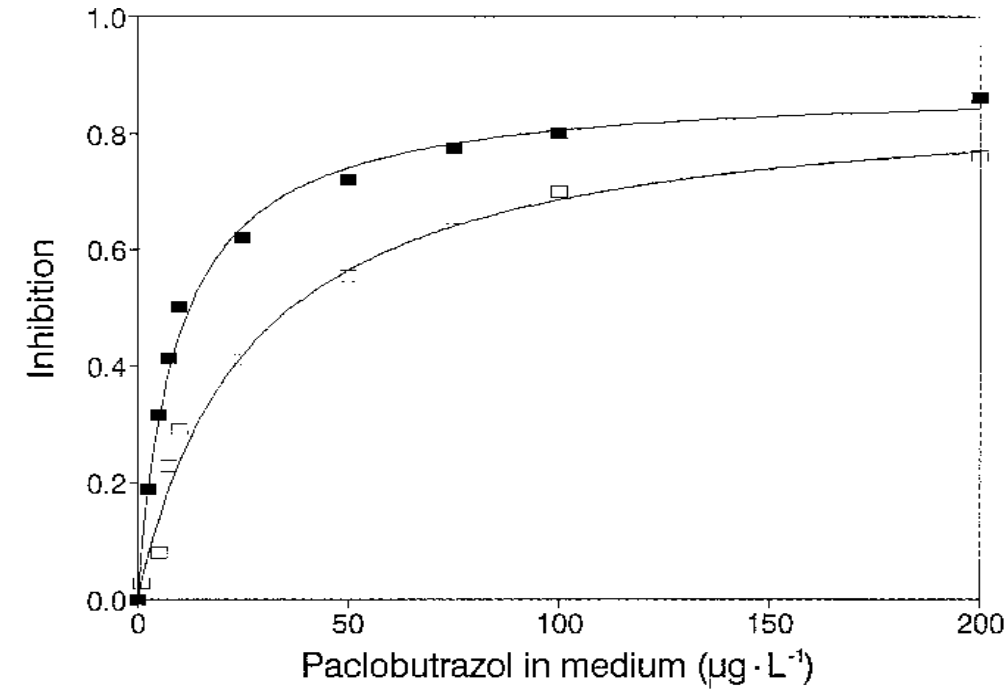

Fig. 1. Standard curves for the broccoli seedling bioassay of paclobutrazol in Metro Mix 500 (MM500), a bark-based medium, and Vergro Klay Mix A (VKMA), a peat-based growing medium. Inhibition was calculated as the percentage reduction in broccoli seedling hypocotyl length relative to the $0 \mu \mathrm{g} \cdot \mathrm{L}^{-1}$ concentration. Regression equations are $\mathrm{y}=0.88 \mathrm{x} /(9.5+\mathrm{x}), r^{2}=0.85$, for VKMA and $0.87 \mathrm{x} /(27.4+\mathrm{x})$,

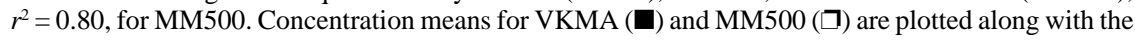
regression curves.

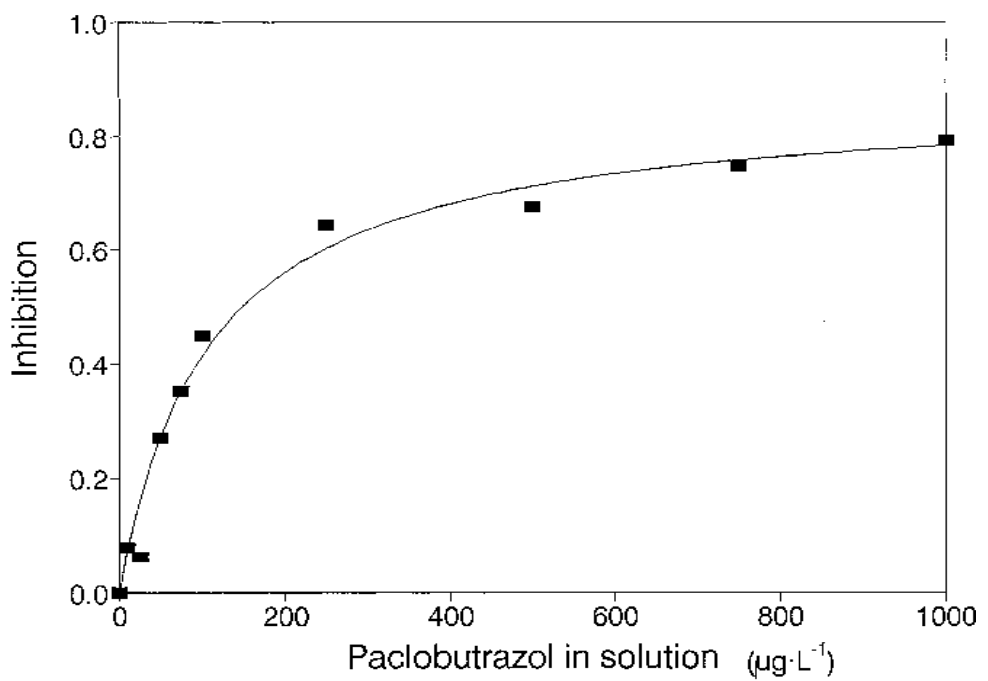

Fig. 2. Standard response curve for the broccoli seedling bioassay of paclobutrazol in solution. Inhibition was calculated as the fractional reduction in broccoli hypocotyl length relative to the $\mu \mathrm{g} \cdot \mathrm{L}^{-1}$ concentration. The regression equation is $\mathrm{y}=0.867 \mathrm{x} /(111+\mathrm{x}), r^{2}=0.79$.

head watering prevented our obtaining any useful information.

Statistical analysis was identical to Expt. 1 except that the main plot factor for the first sampling date was application method instead of medium.

\section{Results and Discussion}

Bioassay and standard curves. A saturation-type response was observed for both media (Fig. 1) and leachate (Fig. 2) bioassay standards. A Michaelis-Menten equation (Causton, 1983) was selected to fit the standard curve data:

$$
y=a x /(b+x)
$$

where $\mathrm{y}=$ inhibition, $\mathrm{x}=$ media paclobutrazol concentration $\left(\mu \mathrm{g} \cdot \mathrm{L}^{-1}\right)$, and $\mathrm{a}$ and $\mathrm{b}$ are param- eters. This equation was chosen because the parameters $a$ and $b$ have useful interpretations. Parameter a is the horizontal asymptote, which represents the maximum inhibition observed, while $b$ represents the concentration at which half the maximum inhibition was observed. Therefore, the parameters could be used to compare paclobutrazol activity in MM500 vs. VKMA. The $95 \%$ confidence intervals for parameter a estimates were $0.874 \pm 0.066$ for MM500 and $0.881 \pm 0.034$ for VKMA, indicating that predicted maximum inhibition for the two media did not differ. However, parameter estimates for $b$ were $27.4 \pm 6.4$ for MM500 and $9.5 \pm 1.5$ for VKMA, indicating that the concentration of paclobutrazol required to achieve one-half maximum observed inhibition was nearly $3 \times$ as high in MM500 as in VKMA. 
Reduced efficacy of paclobutrazol (Million et al, 1998) and ancymidol (Bonaminio and Larsen, 1978; Tschabold et al., 1975) in pine bark-based media has been reported previously. Because MM500 and VKMA differ relative to several components, the reduced activity in MM500 cannot be directly attributed to the bark in this study. However, the procedure for establishing the standard curve was conducted under nonleaching conditions, and the reduced efficacy in MM500 cannot be explained by increased leaching losses caused by the bark component, as proposed by Bhat and Tayama (1990) with ancymidol.

Media effects on drench distribution (Expt. 1). Paclobutrazol concentration was lower in leachates from MM500 than in those from VKMA (Table 1). Considering the leachate volumes collected, total estimated leaching losses of paclobutrazol were 1 and $1.9 \mu \mathrm{g}$ for MM500 and VKMA, respectively. These totals represent $<2 \%$ of the $120 \mu \mathrm{g}$ of paclobutrazol applied, which indicates that leaching during application should not cause a significant loss in chemical efficacy.

Paclobutrazol activity was not uniformly distributed in either media immediately following drench applications (Table 2). Bioassay results on the different sample layers indicated that inhibition (paclobutrazol activity) was highest in the uppermost $2.5 \mathrm{~cm}$ of both media and decreased with depth. This decrease with depth was more pronounced in MM500 than in VKMA (Table 2). Because activity was lower in MM500 than in VKMA for a given concentration of paclobutrazol (Fig. 1), the estimated concentrations of paclobutrazol at each sample depth for both media did not differ significantly (Fig. 3).

The estimated concentration of paclobutrazol was 3 to $4 \times$ as high in the uppermost 2.5 $\mathrm{cm}$ layer than in the lower depths for both media (Fig. 3), indicating that paclobutrazol was being retained by the upper layers of media during the drench application. The type of growing medium affected paclobutrazol activity more than the initial distribution of the chemical during the drench application.

Effect of application method on paclobutrazol distribution (Expt. 2). The standard curve equations used to estimate media concentration of paclobutrazol were:

$$
\mathrm{y}=0.853 \mathrm{x} /(9.16+\mathrm{x}) ; r^{2}=0.89
$$

for the first sample date bioassay, and

$$
\mathrm{y}=0.80 \mathrm{x} /(9.5+\mathrm{x}) ; r^{2}=0.86
$$

for the second. These standard curves were similar to that observed in Expt. 1 (Fig. 1).

The drench application method resulted in more uniform distribution of paclobutrazol activity than did the subirrigation method (Table 3). For the drench application, bioassay activity was distributed mostly in the upper 5 $\mathrm{cm}$ of medium with highest activity observed in the uppermost $2.5 \mathrm{~cm}$. The average application volume was $158 \mathrm{~mL} /$ pot, which is $30 \%$ more than the $120 \mathrm{~mL}$ recommended by the product label. A similar pattern of paclobutrazol distribution was observed in Expt. 1.

For the subirrigation soak method of appli-
Table 1. Broccoli seedling bioassay of leachate following a 120-mL drench application of paclobutrazol to

\begin{tabular}{|c|c|c|c|c|c|}
\hline $\begin{array}{l}\text { Growing } \\
\text { medium }^{2}\end{array}$ & $\begin{array}{c}\text { Paclobutrazol } \\
\text { drench concn } \\
\left(\mu \mathrm{g} \cdot \mathrm{L}^{-1}\right)\end{array}$ & $\begin{array}{c}\begin{array}{c}\text { Leachate } \\
\text { volume } \\
(\mathrm{mL})\end{array} \\
\end{array}$ & $\begin{array}{l}\text { Hypocotyl } \\
\text { length } \\
(\mathrm{cm}) \\
\end{array}$ & Inhibition $^{y}$ & $\begin{array}{c}\text { Leachate } \\
\text { paclobutrazol } \\
\text { concn } \\
\left(\mu \mathrm{g} \cdot \mathrm{L}^{-1}\right)^{\mathrm{x}} \\
\end{array}$ \\
\hline \multirow[t]{2}{*}{ MM500 } & 0 & 48 & 3.0 & --- & --- \\
\hline & 1000 & 49 & 2.6 & 0.13 & 20 \\
\hline \multirow[t]{2}{*}{ VKMA } & 0 & 24 & 3.1 & --- & --- \\
\hline & 1000 & 27 & 2.1 & 0.32 & 70 \\
\hline $\operatorname{LSD}_{0.05}$ & & 7 & 0.2 & 0.05 & --- \\
\hline
\end{tabular}
a 15-cm pot filled with either Metro Mix 500 (MM500) or Vergro Klay Mix A (VKMA) (Expt. 1).

${ }^{2}$ MM500 contained $20 \%$ peat and $40 \%$ composted pine bark; VKMA contained 50\% peatmoss and $0 \%$ composted pine bark.

${ }^{y}$ Inhibition was calculated as the reduction in broccoli seedling hypocotyl length relative to the $0 \mu \mathrm{g} \cdot \mathrm{L}^{-1}$ concentration.

${ }^{\mathrm{x}}$ Estimated concentration based upon standard curve regression equation (Fig. 2).

Table 2. Broccoli seedling bioassay of two commercial growing media sampled immediately following a 120 -mL drench application of paclobutrazol to a $15-\mathrm{cm}$ pot (Expt. 1).

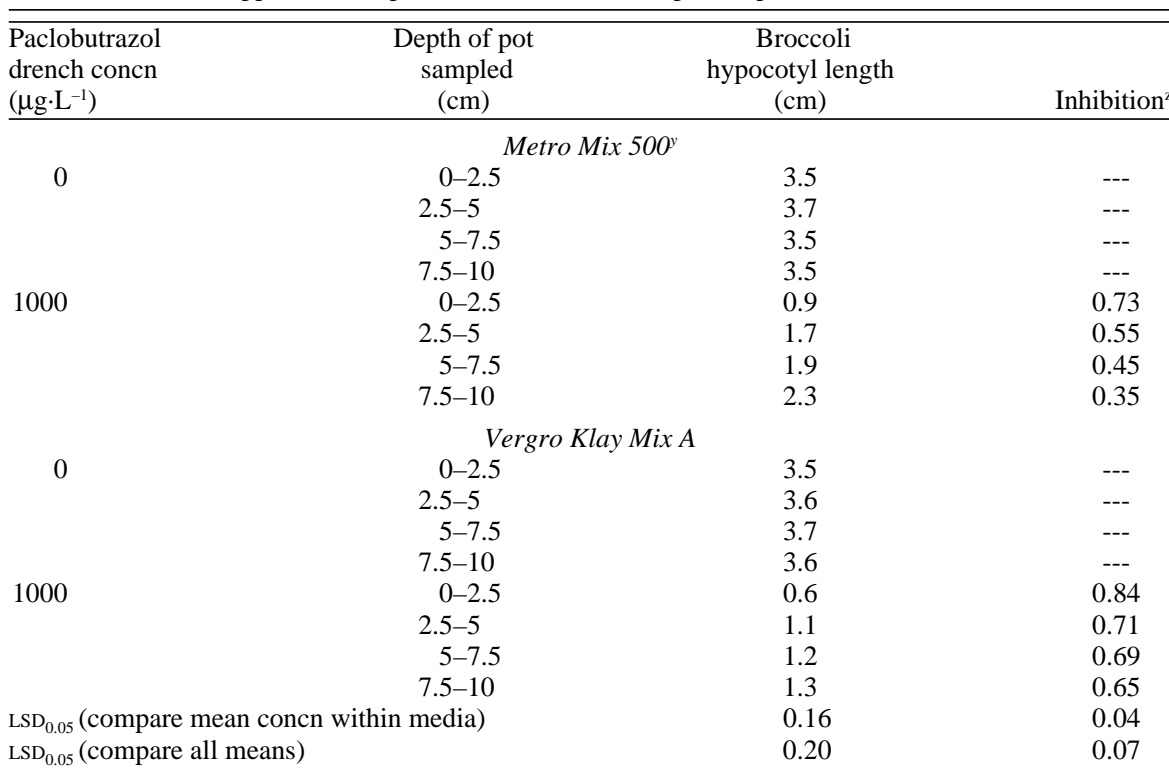

${ }^{2}$ Inhibition was calculated as the reduction in broccoli seedling hypocotyl length relative to the $0 \mu \mathrm{g} \cdot \mathrm{L}^{-1}$ concentration for a given media and depth.

${ }^{y}$ Metro Mix 500 contained 20\% peat and 40\% composted pine bark; Vergro Klay Mix A contained $50 \%$ peat and $0 \%$ composted pine bark.

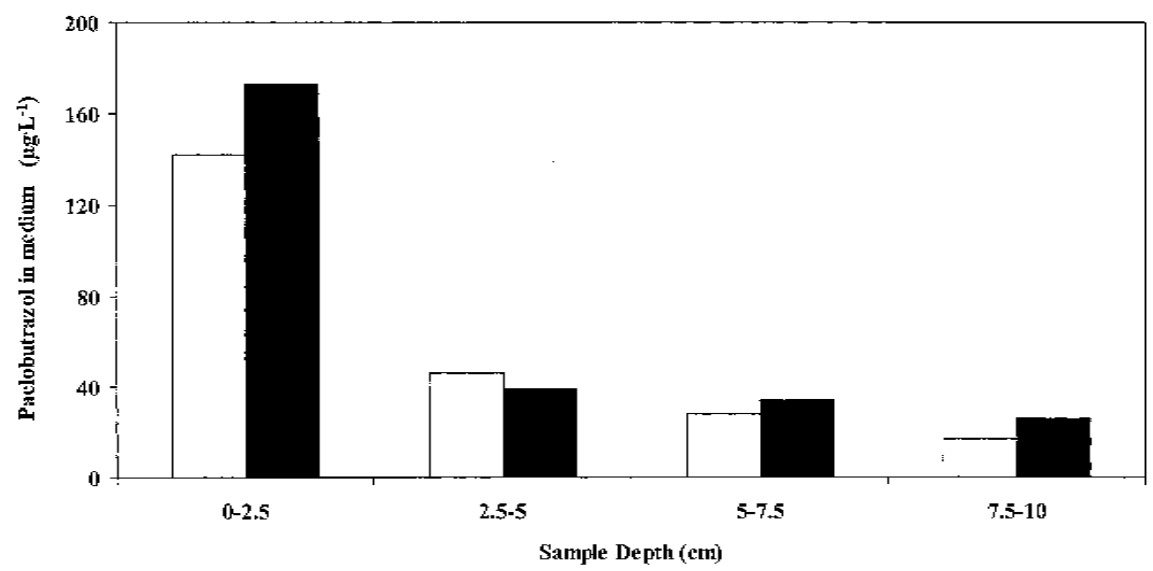

Fig. 3. Distribution of paclobutrazol following the drench application of $120 \mathrm{~mL}$ of a $1000 \mu \mathrm{g} \cdot \mathrm{L}^{-1}$ solution to a $15-\mathrm{cm}$ pot filled with Metro Mix 500 (bark-based) ( $\square$ ) or Vergro Klay Mix A (peat-based) (ם). Concentration of paclobutrazol in media was estimated using bioassay standard curves (Fig. 1). (Expt. 1) 
cation, very little paclobutrazol was detected above the bottom $2.5 \mathrm{~cm}$ of the medium when the medium was sampled immediately after treatment. Upward capillary movement of solution during subirrigation apparently resulted in more effective adsorption by the medium than was evident for the drench application method.

For the 3-week posttreatment period, during which pots were surface-irrigated, paclobutrazol activity in the medium remained relatively constant (Fig. 4). However, estimated concentrations decreased in the top $2.5-\mathrm{cm}$ layer of medium and increased in the lower three layers, indicating that paclobutrazol was being redistributed to the lower portions of the medium.

The bioassay procedure described in this report should be useful in future studies with growth retardants. The bioassay results are obtained within 2 weeks, as broccoli seedlings emerge quickly and are relatively nondemanding in their growth requirement. Furthermore, many seedlings can be grown in a small area, which reduces the variability inherent in bioassay procedures.

\section{Literature Cited}

Barrett, J.E. 1982. Chrysanthemum height control by ancymidol,PP333, and EL-500 dependent on medium composition. HortScience 17:896-897.

Bhat, N.R. and H.K. Tayama. 1990. Retention and distribution of ancymidol in bark-based container growing media. Plant Growth Reg. Soc. Amer. 18:147-154.

Bonaminio, V.P. and R.A. Larson. 1978. Influence of potting media, temperature, and concentration of ancymidol on growth of Chrysanthemum morifolium Ramat. J. Amer. Soc. Hort. Sci. 103:752-756.

Causton, D.R. 1983. A biologist's basic mathematics. Hodder and Stoughton Ltd., London.

Davis, T.D., G.L. Steffens, and N. Sankhla. 1988. Triazole plant growth regulators. Hort. Rev. 10:63-105.

Hunter, D.M. and J.T.A. Proctor. 1990. Paclobutrazol bioassay using axillary growth of a grape shoot. HortScience 25:309-310.

McArthur, D.A.J. and G.W. Eaton. 1987. Effect of fertilizer, paclobutrazol, and chlormequat on strawberry. J. Amer. Soc. Hort. Sci. 112:241246.

Million, J.B., J.E. Barrett, T.A. Nell, and D.G. Clark. 1998. Influence of media components on efficacy of paclobutrazol in inhibiting growth of broccoli and petunia. HortScience 33:852-856.

Reed, A.N. 1988. Quantification of triazole and pyrimidine plant growth retardants. J. Chromatog. 438:393-400.

SAS Institute. 1987. SAS/STAT guide for personal computers. vers. 6. SAS Inst., Cary, N.C.

Tschabold, E.E., W.C. Meredith, L.R. Guse, and E.V. Krumkalns. 1975. Ancymidol performance as altered by potting media composition. J. Amer. Soc. Hort. Sci. 100:142-144.
Table 3. Broccoli seedling bioassay of Vergro Klay Mix A, a peat-based medium containing no bark, sampled immediately after applying paclobutrazol by drench or subirrigation methods to chrysanthemums in $15-\mathrm{cm}$ pots (Expt. 2).

\begin{tabular}{|c|c|c|c|c|}
\hline $\begin{array}{l}\text { Application } \\
\text { method }^{z}\end{array}$ & $\begin{array}{c}\text { Paclobutrazol } \\
\text { concn } \\
\left(\mu \mathrm{g} \cdot \mathrm{L}^{-1}\right)\end{array}$ & $\begin{array}{l}\text { Sample depth } \\
(\mathrm{cm})\end{array}$ & $\begin{array}{c}\text { Broccoli } \\
\text { hypocotyl length } \\
(\mathrm{cm})\end{array}$ & Inhibition $^{y}$ \\
\hline \multirow[t]{8}{*}{ Drench } & 0 & $0-2.5$ & 2.3 & --- \\
\hline & & $2.5-5$ & 2.2 & --- \\
\hline & & $5-7.5$ & 2.4 & --- \\
\hline & & $7.5-10$ & 2.4 & --- \\
\hline & 1000 & $0-2.5$ & 0.6 & 0.75 \\
\hline & & $2.5-5$ & 1.0 & 0.55 \\
\hline & & $5-7.5$ & 2.1 & 0.13 \\
\hline & & $7.5-10$ & 2.2 & 0.10 \\
\hline \multirow[t]{8}{*}{ Subsurface } & 0 & $0-2.5$ & 2.3 & --- \\
\hline & & $2.5-5$ & 2.3 & --- \\
\hline & & $5-7.5$ & 2.3 & --- \\
\hline & & $7.5-10$ & 2.4 & --- \\
\hline & 1000 & $0-2.5$ & 2.3 & -0.01 \\
\hline & & $2.5-5$ & 2.3 & -0.01 \\
\hline & & $5-7.5$ & 2.1 & 0.08 \\
\hline & & $7.5-10$ & 0.9 & 0.63 \\
\hline \multicolumn{3}{|c|}{$\mathrm{HSD}_{0.05}$ (compare mean concn within method) } & 0.19 & 0.07 \\
\hline \multicolumn{3}{|c|}{$\mathrm{HSD}_{0.05}$ (compare all means) } & 0.22 & 0.10 \\
\hline
\end{tabular}

${ }^{2}$ An average of $158 \mathrm{~mL}$ was applied via subirrigation; equivalent drench volumes were applied.

${ }^{\mathrm{y}}$ Inhibition was calculated as the reduction in broccoli seedling hypocotyl length relative to the $0 \mu \mathrm{g} \cdot \mathrm{L}^{-1}$ rate for a given method and sample depth.

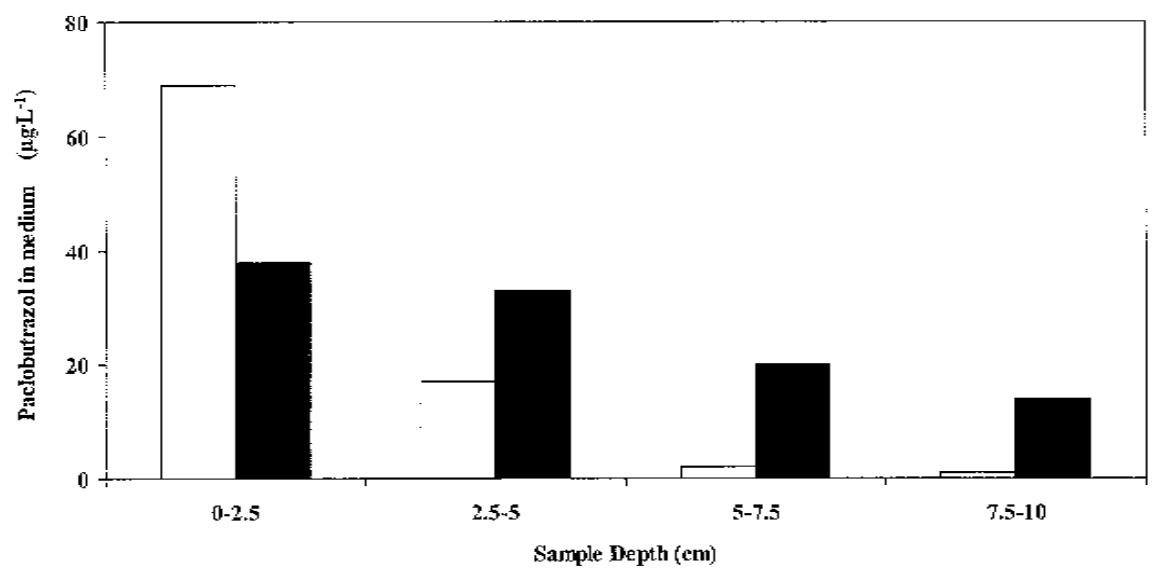

Fig. 4. Distribution of paclobutrazol in Vergro Klay Mix A, a peat-based medium, sampled immediately ( $\square$ ) or 3 weeks after (ם) paclobutrazol drench application of $120 \mathrm{~mL}$ at $500 \mu \mathrm{g} \cdot \mathrm{L}^{-1}$. (Expt. 2). 